\title{
Transport policy for liveability - valuing the impacts on movement, place, and society
}

\author{
Paulo Anciaes \\ Peter Jones \\ University College London, United Kingdom
}

Published in Transportation Research Part A: Policy and Practice 132, 157-173

\begin{abstract}
In many countries, there is a movement away from 'car-centred' policies and a stronger interest in developing healthy, equitable, and sustainable transport systems that enhance liveability. However, the translation of these new priorities into convincing 'economic cases' for funding agencies requires changes in appraisal methods. This paper reviews the state of the art in the appraisal of nine impacts of transport related to liveability: trip quality, time use in transport, place quality, time use in places, personal security, visual blight, community severance, equity/social inclusion, and health/wellbeing. We look at whether and how these impacts are currently appraised in practice and propose alternative methods based on a review of the literature and our suggestions. We found that there are robust methods to measure and monetise some of the impacts, but those methods tend to be integrated in national guidelines and are not always suitable at the city or regional level. Research on stated and revealed preferences methods has moved fast but application faces issues of complexity, transferability, and double counting. It is still difficult to monetise impacts such as time use in transport and visual blight without further methodological developments.
\end{abstract}

\section{Introduction}

Expectations of what transport systems should deliver have evolved over the years. As car ownership and use grew in the 1960s/70s, governments focused on providing for car-based mobility, by investing on road and car parking infrastructure. When congestion and the social and environmental problems of car use emerged, there was an increased interest in public transport and non-motorised modes. In recent years, the priorities of many governments have been to restrain car use (Nieuwenhuijsen and Khreis 2016) in order to not only improve 
conditions for pedestrians and cyclists but also for the use of streets as places, using policies such as restrictions to car movement and parking; road charging; reallocation of road space to pedestrians, cyclists, and street activities; low-speed or low-emission zones; improvement of the public realm; and even the removal of road infrastructure. This change in policy priorities is both cause and effect of a slower growth or a decline in the car modal share, especially in urban areas (Halpern et al. 2018), but it can also be explained by external factors, such as growing public concern about health and wellbeing (WHO 2015, WHO and European Commission 2017) and increased international competitiveness among cities based on highquality built environments (Gospodini 2002, Colomb 2012, Musterd and Kovács 2013).

This change in policy priorities reflects a new transport policy paradigm (Jones 2014, Newman and Kenworthy 2015, Buehler et al. 2017, Jones et al. 2018), where the aim is to develop a healthy, equitable, and sustainable transport system and ultimately to enhance liveability - a concept that can generally be defined as people's ability to access opportunities to improve their quality of life (Appleyard et al. 2014). In the context of the new transport policy paradigm, liveability is specifically related to the idea that the transport system should provide safe, attractive, and enjoyable environments both when people move around (i.e. impacts on movement) and when they use public places (impacts on "place"), as well as enhancing the benefits of those environments for all (impacts on society). This idea is evident in the mobility plans of many cities and regions, especially (but not only) in Western Europe (SenStadt 2011, CRIDF 2014, City of Vienna 2014, City of Copenhagen 2015, Mayor of London 2018), and is often explicit in slogans such as "Let's Fill Streets With Life" (City of Barcelona 2012) and "More Urban Life for All” (City of Copenhagen 2013).

To be effective, this shift in transport priorities requires a parallel change in the indicators to judge the success of the different policies. Indeed, appraisal frameworks that were originally developed to support investment in roads (and which emphasized indicators such as road capacity, average speeds, travel time, and parking provision), have been expanded to include indicators of the performance of the transport system as a whole and its impacts on the economy (e.g. employment), society (e.g. accidents), and environment (e.g. noise, air pollution). However, current appraisal frameworks only partially take into account the concerns of a transport policy focused on liveability. Even when these concerns are included in appraisal, they are seldom quantified and rarely monetised. As evident in the international reviews of Odgaard et al. (2005) and Mackie and Worsley (2013), national guidance for transport appraisal is still centred on travel time savings, while research on external costs (CE 
Delft et al. 2011, Korzhenevych et al. 2014) has mostly focused on environmental impacts. Social impacts have received much less attention (Geurs et al. 2009). There are also few appraisal frameworks at the city-level, where national guidance may not be suitable due to the smaller scale of the projects.

There is therefore a gap between what governments want to do and what they can justify to funding agencies, as it is harder to make an economic case for investing in liveability (i.e. improving both movement and place, while attending to broader social issues) than simply for facilitating movement. This is because the tendency in transport appraisal has been to move towards monetisation (Mackie and Worsley 2013 p. 6). When the assessment of an impact is not quantitative (which is the case for most social impacts), the process is "largely judgemental and undocumented" (Mackie and Worsley 2013 p.13) and the impact tends to be disregarded because its implicit value in cost-benefit analysis "appears to be zero" (Pearce et al. 2006 p.31).

Notwithstanding this general situation, some transport authorities have started to adopt methods to assess how transport enables liveability. For example, the Mayor of London's new transport strategy is centred on the concept of "Healthy Streets", a multi-indicator approach to assess human health and experience in the city (Mayor of London 2018, TfL 2017a), and one of the pillars of the UK Department for Transport's new strategy for appraisal is the impact on "people and places" (DfT 2019). The new manual for transport appraisal in Australia also has a chapter on "urban amenity and liveability" (ATAP 2018) and the one in Norway has a chapter on "community life and outdoor recreation" (Vegdirektoratet 2018 Ch.6.5). At the same time, researchers have developed new methods aligned with the governments' new priorities. Most of these methods derive values from stated preference surveys (where people choose among hypothetical alternatives) or revealed preferences models (using choices observed in markets).

This paper reviews the state of the art in practice and research on these new appraisal methods, looking at nine impacts that are judged to be suitable indicators for assessing the performance of transport policies that provide for liveability.

The selection of these impacts was a 3-step process. In the first step, we identified the liveability impacts of transport policies that are mentioned in the mobility plans and related official documents of cities around the world where there was a reduction in the car modal share in recent decades. In the second step, we identified the impacts that are distinctive of this type of cities, based on the results of interviews and focus groups (documented in Halpern 
et al. 2018 and Cavoli 2018) with practitioners in two groups of cities, one including five cities (London, Paris, Berlin, Vienna, and Copenhagen) where the car model share has been decreasing, and another including five cities (Tallinn, Bucharest, Skopje, Adana, and Amman) where the car modal share is still growing. In the third step, the list of impacts was refined following discussions in a workshop (organised as part of the EU-funded CREATE project) with representatives from the transport authorities of the 10 cities mentioned above.

Figure 1 shows the nine selected impacts. When planning transport for liveability, there is an increased emphasis on aspects of movement other than travel time, such as trip quality and how people use their time while travelling (CRIDF 2014 Ch.3.1-3.2; Mayor of London 2018 Ch.4; TfL 2018a, 2018b). It is also recognized that streets have a "place" function and, as such, transport policies influence the quality of public places (TfL 2017a; City of Copenhagen 2009, 2013; SenStadt 2011 Ch.4.4.3) and how people use their time in those places (City of Copenhagen 2013). There is also increased concern with how movement and place is related to society, including aspects such as perceptions of personal security in transport and public places (Mayor of London 2018 Ch.3), how transport infrastructure and motorised traffic cause visual blight (SenStadt 2011 Ch.4.4.3) and act as barriers separating communities (CRIDF 2014 Ch.3.1), and how transport reinforces inequalities and social exclusion (City of Copenhagen 2015, SenStadt 2011 Ch.4.4.3, City of Vienna 2014 Ch.3) and affect health and wellbeing (TfL 2014, 2017a; CRIDF 2014 Ch.1; City of Vienna 2014 Ch.3).

Figure 1: Nine relevant liveability impacts of transport

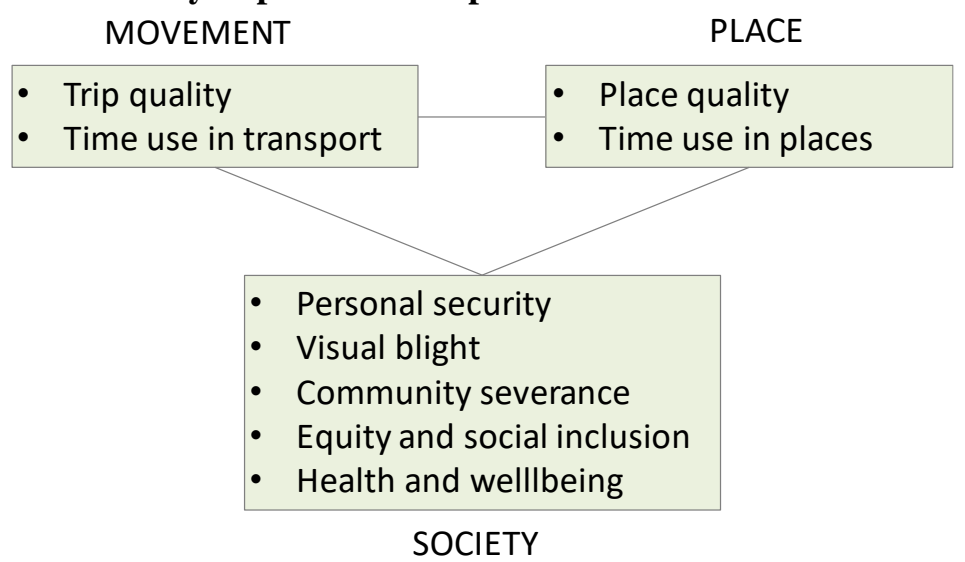

It should be emphasized that these nine impacts do not exhaust the concept of liveability or any of the three components (movement, place, and society) in which we organised that concept. Liveability is also related to transport impacts such as air pollution, noise, and safety (from traffic collisions). However, as previously mentioned, these impacts have already been 
included in appraisal frameworks before the new transport policy paradigm became prominent, and as such, they are not distinctive of this paradigm. In addition, there is already extensive knowledge on methods to assess these impacts (e.g. CE Delft et al. 2011, Korzhenevych et al. 2014), many of them applied in practice. For these reasons, these impacts are not reviewed in this paper.

The rest of the paper reviews the selected impacts on movement (Section 2), place (Section 3) and society (Section 4) using a common structure with four headings for each impact. Under the first heading ("What is this impact?"), we define the impact and explain the theory about its relationship with transport, aspects of liveability, and with the other impacts (identified in bold in the text). We also identify the policies that have been used to tackle the impact. Under the second heading ("How is this impact assessed"?), we look at whether and how the impact is currently measured and monetised by practitioners, as described in documents issued by national, regional, or city governments around the world (not limited to the European cities mentioned above). Under the third heading ("How could the impact be assessed?"), we propose alternative methods, some from existing academic and 'grey' literature and others based on our suggestions. The fourth heading ("What are the main issues"?) discusses the main gaps and theoretical and practical issues of the existing and potential methods. In Section 5, we bring together the findings of the review of the nine impacts and discuss overall issues.

\section{Movement}

\subsection{Trip quality}

\section{What is this impact?}

The concept of trip quality usually refers to the subjective experience of all aspects of trips other than cost and travel time. These aspects differ by travel mode (Table 1).

Table 1: Trip attributes by travel mode

\begin{tabular}{ll}
\hline Travel mode & \multicolumn{1}{c}{ Trip attributes } \\
\hline Public transport & $\begin{array}{l}\text { facilities at stations/bus stops, information, crowding, comfort, in-vehicle amenities, } \\
\text { cleanliness, physical accessibility }\end{array}$ \\
\hline Walking & $\begin{array}{l}\text { pavement width/condition, legibility, obstructions, street environment, amenities, } \\
\text { provision for the mobility-impaired }\end{array}$ \\
\hline Cycling & dedicated lanes, route conditions, parking facilities, cycle hire facilities \\
\hline
\end{tabular}


There is extensive evidence that trip quality affects travel behaviour. For example, the comfort and convenience of public transport are often identified as possible factors contributing to a modal shift away from car travel (Redman et al. 2013). The quality of pedestrian and cycling infrastructure and street environment also influences both the propensity for walking and cycling (Saelens et al. 2003) and route choice (Muraleetharan and Hagiwara 2007, Guo and Loo 2013). Aspects of trip quality such as comfort and the conditions of the indoor environment are also associated with time use in public transport (Zhang and Timmermans 2010) and with commuter stress and satisfaction with travel, with consequences on health and wellbeing (Friman et al. 2017). Aspects of trip quality related to physical accessibility can also become barriers for some individuals to use transport and access destinations, increasing the probability of social exclusion (Titheridge et al. 2009).

Trip quality has been addressed by improving public transport infrastructure and services and walking, and cycling infrastructure, often through interventions that reduce the mobility of car users, such as the reallocation of roadspace (Cairns et al. 2002) and car traffic restrictions (European Commission 2004).

\section{How is this impact assessed?}

Many local governments and public transport operators use indicators of the "level of service" of public transport, using data from customer surveys (ITF 2014 Ch.2, Oña and Oña 2015). The assessment of walking and cycling trips often uses street audit tools (Day et al. 2005, Cain et al. 2012, TRL 2010) which rely on subjective ratings of multiple attributes, which are then combined into an overall score. Surveys are also often used to assess perceptions and satisfaction about walking and cycling. The City of Copenhagen has a more structured process to appraise cycle projects, often using economic evaluation (COWI 2009).

It is common to use 'multipliers' of in-vehicle travel time for assessing crowding in public transport (ITF 2014 Ch.1). Improvements can be converted into reductions of travel time, and then into reductions of the generalised travel cost, and finally used to estimate change in travel demand and consumer surplus. This is the approach suggested in England by DfT (DfT 2017 Ch.6) for improvements to bus trips. In Sweden, a similar approach is applied to adjust travel time for cyclists and pedestrians according to the type of infrastructure (segregated or mixed with other users) (Trafikverket 2018 Ch. 7.6).

Some governments suggest monetising trip quality directly. For example, Transport for London uses an "Ambience Benefits Calculator", which involves the assessments of attributes specific to each travel mode, using qualitative scales. These assessments are then combined 
with unit monetary values. However, the origin of these values in unclear, both in the calculator and in supporting documentation (TfL 2017b Ch.16). The guidance in New South Wales in Australia includes values for attributes of public transport stations and vehicles, from previous studies based on passengers' stated preferences and ratings of trip attributes (in comparison with ratings of travel time) (TfNSW 2016 A4-10). The guidance in England and Ireland also suggest values for the improvement of pedestrian and cycling infrastructure, from previous stated preference studies, but emphasize that the application of these values is limited by the fact that they were derived in specific contexts, and suggest using local values whenever possible (DfT 2017 Ch.6.3.5, TII 2016a p.11).

\section{How could the impact be assessed?}

There is an extensive literature estimating the willingness to pay for attributes of public transport trips (see a review in De Gruyter et al. 2019). These studies could be enhanced by new data from smart-card payment systems (Jánošíková et al. 2014) and surveys implemented in GPS-enabled smartphones (Liotopoulos 2017), which could provide a richer representation of how the choices of travellers are affected by the travel experience.

Stated preference methods have also been used to value attributes of cycling trips such as cycle lane design, parking availability, and lighting (Tilahun et al. 2007, Börjesson and Eliasson 2012, Poorfakhraei and Rowangould 2015) but there is less evidence for walking trips (but see Sheldon et al. 2007 and Kelly et al. 2011). Revealed preferences methods could also be used to model walking route choices (Muraleetharan and Hagiwara 2007, Guo and Loo 2013). The estimated detours to avoid certain features of the route could then be converted into monetary values.

\section{What are the main issues?}

Research on public transport service quality has moved fast and produced sophisticated measures that are difficult to apply in contexts other than large cities (Guirao et al. 2016). Street audit tools are also more suitable to assess present conditions than to forecast future conditions (but see Anciaes and Jones 2016). It is also not clear how to forecast and aggregate preferences about trip quality, as they depend on demographics (Susilo and Abenoza 2017) and the spatial and temporal context (Becker and Albers 2016), which limits the transferability of values. There may also be a 'package effect' in trip quality. Summing individual trip attribute values may over- or under-estimate the value of the total package. 


\subsection{Time use in transport}

\section{What is this impact?}

Travel time has traditionally been regarded as something to be minimized because it has an opportunity cost, i.e. it is time not use for other activities. However, there is increased recognition that under some circumstances, travel time can also have a positive utility, because it is regarded as enjoyable or productive (Mokhtarian and Salomon 2001, Redmond and Mokhtarian 2001, Lyons et al. 2007, Jain and Lyons 2008). Public transport users can now use personal electronic devices for work, entertainment, or communication while travelling. According to Van Hagen et al. (2009) even waiting time is "becoming fun" because passengers enjoy advertising and 'infotainment' at stations. Pedestrians also use travel time for activities such as window shopping, talking to others, and use of street furniture (Kim 2015). Users of all modes use travel time for thinking, enjoying the scenery, relaxing, and social interaction.

The possibility of using travel time may affect travel behaviour, contributing to a modal shift towards public transport (Malokin et al. 2019). It also has a positive effect on travel satisfaction, with impacts on wellbeing (Ettema et al. 2012, Rhee et al. 2013). The opportunity for social interaction in public transport has also been positively associated with wellbeing among the elderly (Green et al. 2014), and may reduce the probability of social exclusion (Currie and Stanley 2008).

Improvements in the ability to use travel time use have been achieved by provision of better facilities in public transport stations and vehicles (e.g. Wi-Fi, sockets) and by policies aimed at general trip quality, mentioned in the previous section.

\section{How is this impact assessed?}

The utility of enjoyable or productive travel time is usually not included in transport appraisal. In theory, this utility is reflected in the estimated values of time (Kouwenhoven and De Jong 2018). However, there are no robust methods to disentangle this utility from the opportunity cost of the time spent (Wardman and Lyons 2016).

\section{How could the impact be assessed?}

There is a growing literature using structured observation, on-board questionnaires, and broader time-use surveys to identify the type and duration of the activities people engaged in while travelling in public transport (see a review in Keseru and Macharis 2018). These 
methods are more difficult to apply in the case of walking and cycling. Using these methods in transport appraisal also requires going beyond 'snapshots' of the current situation and build models to predict how use of travel time responds to trip attributes, an area with little research (but see Guo et al. 2015).

Methods allowing the monetisation of travel time use are still rare. Several studies estimated the probabilities that travellers found travel time worthwhile (Rasouli and Timmermans 2014, Frei et al. 2015) but stopped short of quantifying that worth. However, Ettema and Verschuren (2007) used stated preference methods to explain the choice between car and public transport based on cost, travel time, and use of that time. Similar methods could be used to estimate the trade-offs between productive or enjoyable uses of public transport travel time (using proxies such as the availability of Wi-Fi and sockets) and other trip attributes.

More indirect approaches could include:

- Estimate the impact of travel time uses on choices over number of trips and travel mode and then value the economic, social, and environmental outcomes.

- Estimate and then value the impacts of travel time use on productivity, learning, social interaction, and wellbeing.

\section{What are the main issues?}

Measuring the time and value of each activity is limited by the fact that travellers engage in a wide range of activities, sometimes simultaneously. It is also difficult to anticipate future possibilities for these activities, given the rapid advances in transport technology and personal electronic devices.

There are also issues when including this impact in cost-benefit analysis, as it opens the possibility of including travel time with both positive and negative values in the same framework. It is not clear whether these values are compensatory, i.e. if the benefit of productive/enjoyable travel time could be subtracted from the opportunity cost of travel time.

Valuing time spent in transport also creates a policy dilemma: if public transport travel time has both a cost and a benefit, while car travel time only a cost, then there is a higher policy priority for reducing car travel time, unless the potential economic, social, and environmental benefits of increased public transport demand are also highlighted in the appraisal. 


\section{Place}

\subsection{Place quality}

\section{What is this impact?}

Streets are not only links for movement but also places used by travellers, local residents/workers, and visitors (Figure 2). Many rail/metro stations are also used by nontravellers for shopping and leisure. Perceptions about the quality of these places depend on a wide range of elements, including the built and natural environment, opportunities for activities, perceived safety, wider environmental conditions (e.g. noise, air pollution), and subjective elements usually described as "sense of place" (Canter 1977). Perceptions of place quality tend to be negatively affected by high motorised traffic volumes and speeds (Mullan 2003, Mahmoudi and Ahmad 2015).

\section{Figure 2: Example of street used as a place}

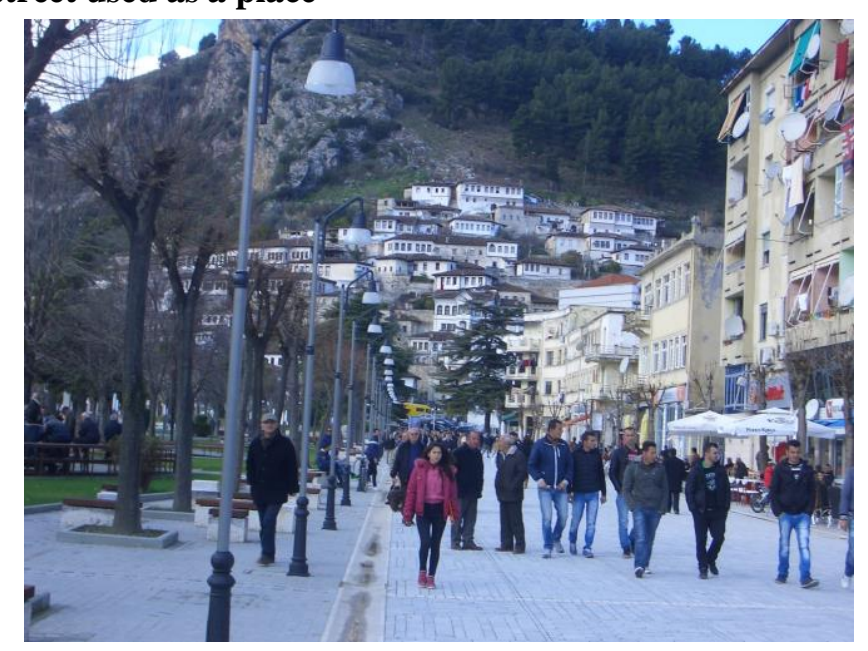

The quality of public places influences the quantity and quality of the time people spend in them (Gehl 1971, 2010). There is also extensive evidence, reviewed in CABE (2001) and Carmona et al. (2010, 2018), of several positive outcomes, both for the users of the places and for residents in the surrounding areas, including reduced crime and fear of crime (increasing personal security), increased neighbourhood satisfaction, improved mental health and wellbeing, vitality of local businesses, and community cohesion.

Policies that enhance place quality include the improvement of stations and bus stops, street redesign (including reallocation of space to pedestrians and street activities) (NACTO 2016), improvement of the public realm (NYC DoT and Gehl Architects 2008), restrictions to car movement and parking (European Commission 2004), low-speed/pedestrian-friendly zones 
(Biddulph 2012) and in general, policies aiming at reducing motorised traffic volumes and speeds.

\section{How is this impact assessed?}

Jones et al. (2007) developed an appraisal framework for street planning and design that balances the characteristics that contribute to the movement and place functions of the street, using a mix of objective measurements and professional and stakeholder judgement. This framework has been applied in several cities (Austroads 2016, TfL 2017c). The quality of public places is also measured by street audit tools that focus on how people feel in public spaces (Ewing and Clemente 2013) and by statistics on the number and diversity of users and activities that take place on those places (Gehl Institute n.d.). Another alternative is public attitude surveys about perceptions of different elements of places, current levels of satisfaction, and priorities for improvement.

Monetization is less common. Transport for London uses a 'Valuing Urban Realm Toolkit' (TfL 2017b Ch. 16.4) to estimate the value of improvements to public places based on user benefit and forecasts of changes in residential land values and retail rents. Many cities, such as New York, have also conducted evaluation studies of place quality (NYC DoT 2012, 2013), but there are fewer examples of appraisal studies. In contrast, property developers often use forecasts of footfall, customer expenditure, and property values to inform plans for public spaces in new developments.

\section{How could the impact be assessed?}

Several studies have used stated preference surveys to value the quality of public spaces. Sheldon et al. (2007), ITS and Atkins (2011), and DEFRA (2013) estimated willingness to pay for improvements in individual components of a place (e.g. seating, plants, litter, graffiti). Other studies have used information on private investment, new businesses, retail sales, and residential, office, or retail property values/rents to estimate the value of improvements or differences across a city in the quality of public spaces (CABE Space 2007, Carmona et al. 2018) and public areas in rail stations (SDG 2011, Centre for London 2017). Stated and revealed preferences have also been used to value specific elements such as street trees (Giergiczny and Kronenberg 2014, Donovan and Butry 2010). Another possibility could be to estimate the effects of improvements to places on individual outcomes (e.g. wellbeing) and/or social outcomes (e.g. community cohesion) and then value those outcomes. 


\section{What are the main issues?}

Place quality is difficult to measure as it depends on how the places are used, by whom, and when, which is difficult to forecast. Users also have different perceptions about the different elements of places and the activities that occur on them. The overall value of places may also be bigger than the sum of the individual components that are captured by stated and revealed preference methods. People might even form an overall perception about a city, not about individual places, and so the best approach might be to value a portfolio of interventions in several places. It is also difficult to capture the full scope of benefits of places, which have regular and sporadic users. Current methods also do not capture trade-offs between place quality and local concerns about aspects such as noise, reduced parking availability, and gentrification.

\subsection{Time use in places}

\section{What is this impact?}

Public spaces used for transport, such as streets and stations, have several uses involving people spending time (for example, for relaxing, shopping, or social interaction), to which individuals attach value. The number of people spending time in a place, and the amount of time they spend in that place depends on its location, in relation to the areas where people live and work, and on the different elements of place quality mentioned in the previous section (Gehl 1971, 2010). In particular, there is consistent evidence that motorised traffic negatively affects the level of street activity (Appleyard et al. 1981, Bosselmann et al. 1999, Sauter and Huettenmoser 2008).

Time spent in public places for relaxation, social interaction, and physical activity, is associated with a reduced risk of social exclusion and improved physical and mental health and wellbeing (Cattell et al. 2008, Walton 2014).

Policies aimed at place quality, mentioned in the previous section, have also been used to enhance the opportunities for people to spend more time in public places (see for example City of Copenhagen 2009).

\section{How is this impact assessed?}

Most transport appraisal methods in use implicitly assume that the objective of transport policies is to save time and do not value the time spent on public spaces. However, there is a long history of research on observational methods to record the time people spend doing 
different activities in public spaces (Gehl 1971, Whyte 1980), something that is routinely assessed by the city of Copenhagen (City of Copenhagen 2013) and increasingly in other cities (see Gehl and J. Max Bond Center 2015 in New York). Property developers are also interested in forecasting the 'dwell time' in the public spaces in planned developments (and the associated retail expenditure).

\section{How could the impact be assessed?}

The economic cost or the market price of goods and services consumed while spending time in a place could be used as a proxy for the value of that time. This could be for example:

- The per-hour cost of providing services in public places, such as rents of market stalls.

- The per-hour price of facilities enabling certain activities, for example, the price of using park deck chairs and outdoor sports areas.

- Differences between prices of comparable products; for example, food and drinks from a take-away and from a shop with seating area.

Stated preference surveys could also be used to estimate the trade-offs people make between time spent in places and time spent working (which is associated with extra income) or between time spent in places and the price of goods and services consumed while spending that time.

Observational methods could also be enhanced by new types of data provided by sensors installed on street furniture (Civic Data Design Lab and Gehl Institute 2017), automated interpretation of online street images (Yin et al. 2015) or geotagged posts in social media (Cheliotis 2016).

\section{What are the main issues?}

It is difficult to forecast how much time people will spend in new or improved public spaces because it depends on mobility patterns, the local political and economic context at different times, perceptions about other groups using the same space, historical, cultural, and social aspects, and how the spaces are used in the first few weeks after the intervention. The values also depend on the type of activities, each having a different per-minute value. Measuring and aggregating all these values is a complex task. In addition, the value is likely to be derived from having the activity (vs. not having), or from its regularity, and cannot simply be reduced to a "value per minute". 


\section{Society}

\subsection{Personal security}

\section{What is this impact?}

Personal security is a major concern in many spaces associated with the transport system (Loukaitou-Sideris 2012, Ceccato et al. 2013, Stucky et al. 2017). This includes for example public transport vehicles and waiting areas (both in the quiet and very busy periods), car parks, secluded pedestrian infrastructure (e.g. underpasses and footbridges) and narrow streets alongside major transport infrastructure (Figure 3).

Figure 3: Example of personal security issue in alleyway next to a railway line

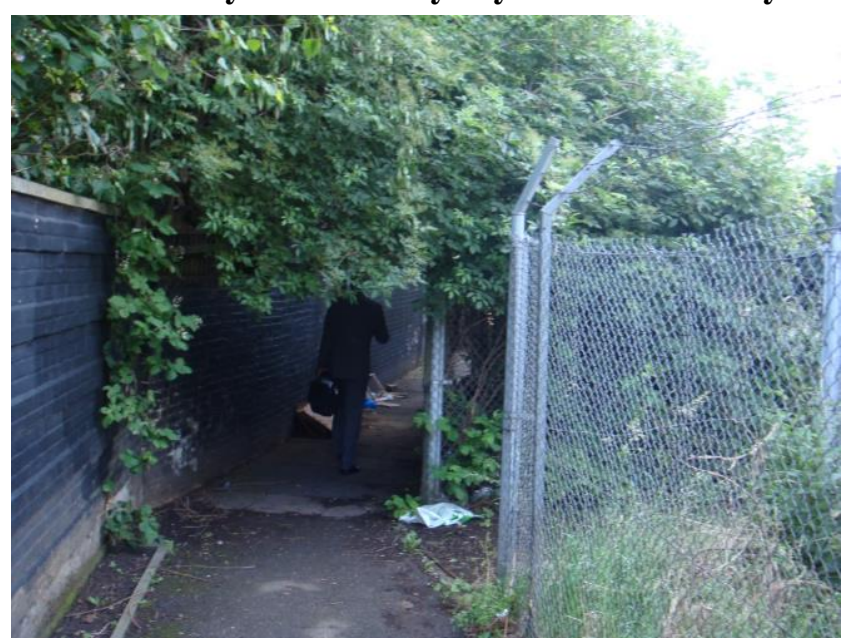

Personal security issues are important not only because of the material and human losses related to crime incidents but also because fear of crime influences perceptions of trip quality and place quality, reduce time spent in places, and is a source of stress (which in turn influences health and wellbeing). Fear of crime also affects travel behaviour, reducing number of trips and the propensity to walk or use public transport (Backer-Grøndahl et al. 2009, Loukaitou-Sideris 2014a). Trip suppression then limits the individual's ability to participate in employment (especially evening/night shifts) and other activities, increasing the risk of social exclusion (Hine and Mitchell 2003). There is an equity dimension to these impacts, as some groups are particularly vulnerable to crime, including women (LoukaitouSideris 2014b), older people (Ceccato and Bamzar 2016), and ethnic minorities (DfT 2003). Because of fear of crime, pedestrians may also avoid using underpasses and footbridges and cross roads in unsafe places, increasing risk of collision (Oviedo-Trespalacios and ScottParker 2017). 
Ensuring personal security is a growing concern of transport policy, evident in interventions to improve the design and environment of streets, stations, bus stops, and pedestrian infrastructure (Lorenc et al. 2013).

\section{How is this impact assessed?}

Personal security is usually measured with qualitative scales, as part of safety audits done by governments or public transport operators. The assessment for pedestrians and cyclists is based on environmental variables (e.g. landscaping, litter, graffiti) and existence of formal and informal surveillance. The assessment for public transport users is based on the characteristics of stations/bus stops, and vehicles. This includes lighting and visibility, surveillance, and facilities (e.g. customer alarms, emergency exits). Again, this type of audits is more useful to assess the current situation than to forecast improvements that could be input in project appraisal.

The effects of transport policies on personal security are seldom monetised. Some transport authorities (e.g. TfL 2017b) use fixed unit costs of different types of crime, from nationallevel studies of the direct and indirect costs of crime. However, those unit costs need to be combined with case-specific forecasts of the impact of policies on the number of crime incidents. As an alternative, personal security can be integrated in appraisal as a multiplier of travel time. For example, national guidance in Sweden recommends a multiplier for the value of women's walking time in unsafe environments (Trafikverket 2018 Ch.17.3).

\section{How could the impact be assessed?}

There is some literature evaluating the effects of transport-related policy interventions such as improved street lighting (Painter and Farrington 2001), video surveillance (Gill and Spriggs 2005), and "alley gating" (Bowers et al. 2004 on crime reduction and then monetizing that reduction using unit values of the cost of crime. Lawson et al. (2018) used some of these results to run simulations of the cost-benefit performance of different types of interventions.

An alternative is to value improved perceptions about personal security, using stated or revealed preferences methods. For example, Willis et al. (2005) estimated the value of street lighting using contingent valuation (i.e. a bid game) and Börjesson (2012) used a choice experiment to estimate the value of safer environments when using and accessing public transport. Hedonic models of house prices can also measure the value of reduced perceptions of crime (but not necessarily linked to transport issues) (Buonanno et al. 2013). 
Another possibility is to use surveys to forecast the number of people who are currently dissuaded from using public transport (and do not make the trip at all) due to personal security issues and who would start using it if those issues were solved. The value of the new trips could then be estimated.

\section{What are the main issues?}

It is difficult to anticipate the effect of specific transport policies on the number of crime incidents or the fear of crime. Localised interventions may also displace crime to other areas. Using estimates from evaluation studies done elsewhere is an imperfect solution as reviews have shown that the evidence on the links between transport-related interventions and crime reduction is mixed (Farrington et al. 2007, Lorenc et al. 2013, Sidebottom et al. 2018) and even when evidence is consistent, the size of the effects varies widely in different sites (Welsh and Farrington 2008, 2009). In general, it is difficult to disentangle the effects of the improvements from the specific conditions of each site. At a conceptual level, monetisation may be regarded as an unsuitable method to assess personal security in transport, given the multiplicity of potential implications of crime and fear of crime for individuals and society.

\subsection{Visual blight}

\section{What is this impact?}

Transport infrastructure has a marked impact on the visual environment (which is one of the most defining experiences people have of the areas where they live or work). Large or elevated roads and railways (Figure 4) intrude on the visual field of pedestrians and of people at home and are often perceived as aesthetically unpleasant (Yamada et al. 1987, Jiang et al. 2015). Noise barriers often aggravate the problem (Arenas 2008, Jiang and Kang 2016). The sight of large volumes of cars (especially heavy goods vehicles), either moving (Jiang and Kang 2016) or parked (Bayley et al. 2004) has also been reported as a negative element of the local visual environment. 
Figure 4: Example of visual blight caused by elevated road

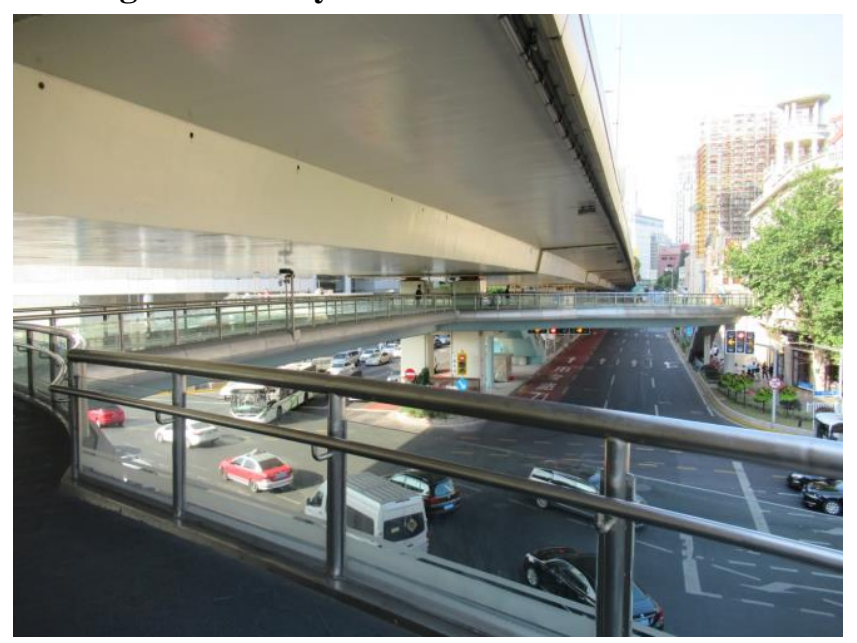

Visual blight may contribute to perceptions of transport infrastructure as a barrier to movement, increasing community severance (James et al. 2005 Ch.6) and of the surrounding area as "ugly" or desolate, reducing perceived place quality (Jiang et al. 2015) and possibly also walking trip quality, time spent in places, and personal security, although there is still little empirical evidence on these effects. More generally, visual impacts decrease people's enjoyment of their local areas with implications on wellbeing (Kaplan 2001), neighbourhood satisfaction (Kaplan 2001, Hamersma et al. 2014), and community cohesion (Mullan 2013).

The reduction of visual impacts is one of the motivations for projects to improve the public realm on and around major roads (ULI 2016) and for removing large road infrastructure (Bocarejo et al. 2012).

\section{How is this impact assessed?}

Guidance on the visual impact assessment of road projects usually relies on the estimation of viewsheds (the area of land that is visible from a location), combined with indicators of exposure (e.g. proximity, number of people affected, and duration). However, this guidance tends to focus on projects in natural areas, not densely populated urban areas (see Highways Agency 2010), and in some cases is skewed towards the impacts of the surrounding visual environment on car users, not the impacts of the road itself on people in the surrounding areas (see US DOT 2015).

There is also little information on how to include these assessments in project appraisal. National guidance in Ireland suggests a scoring system which is then integrated in a multicriteria analysis (TII 2016b Ch.3.1.9). The guidance in England, Norway, Switzerland, and New Zealand recommend qualitative scales or descriptive assessments only (DfT 2017 Ch.7, 
Vegdirektoratet 2018 Ch.4, ASTRA 2018 Ch.4.4SE4, NZTA 2018 Ch.A8.7/A8.9). There are currently no methods used in practice to monetise visual impacts. The guidance in Switzerland suggests unit monetary values but these originate from a study of natural areas, not built-up areas.

\section{How could the impact be assessed?}

Research has focused on the impacts of new roads in natural areas and there are few methods for projects to mitigate or remove the impacts of existing roads (and other transport infrastructure) on pedestrians and non-users in urban areas. However, Jiang et al. (2015) suggested a method combining GIS mapping with rating surveys. There are also more general visual preference surveys about the overall local environment (Ewing et al. 2015), which could be enhanced by new eye tracking technologies (Noland et al. 2017).

Even exhaustive studies of environmental impacts did not attempt to monetise visual impacts as they are "very difficult to measure and no reliable estimates are available" (CE Delft et al. 2011 p.68). But some studies have used revealed preference methods to value these impacts as a part of wider set of local environmental attributes. For example, Bateman et al. (2001) found a negative association between property prices and the impact of roads on viewsheds from the properties. Eliasson et al. (2002) use a stated preference survey to estimate trade-offs between different types of screening of roads and railways (fences, walls, embankments) and other impacts such as severance. Another possibility is to quantify and then value the consequences of visual blight on wellbeing or neighbourhood satisfaction.

\section{What are the main issues?}

Visual impacts are particularly difficult to measure and monetise because they depend on personal aesthetics. There are also problems in transferring values, because the impacts are highly site-specific. It is also possible that the perception of the impact changes over time, as people adapt to their visual environment.

\subsection{Community severance}

\section{What is this impact?}

Community severance happens when large transport infrastructure (such as motorways and railways), or high motorised traffic volumes and speeds, are a physical or psychological 
barrier limiting the mobility of pedestrians and cyclists and separating communities (Figure 5) (Anciaes et al. 2016, Mindell et al. 2017).

Figure 5: Example of community severance caused by a road

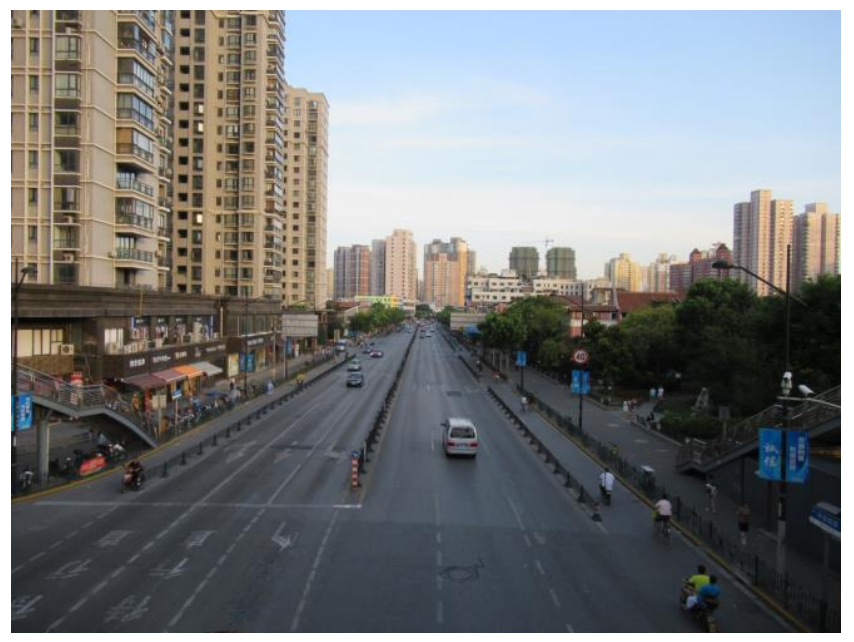

Severance may cause people to suppress walking or cycling trips (Jacobsen et al. 2009), which contributes to lower levels of physical activity (Jerrett et al. 2010) and accessibility to goods, services, and opportunities (Mindell and Karlsen 2012). Severance also reduces the use of streets as social spaces, reducing time spent in places (Appleyard et al. 1981, Bosselmann et al. 1999) and negatively influencing perceptions of personal security in the areas around the infrastructure (Jacobs 1961). All these effects then have potential negative consequences on social exclusion (Sauter and Huettenmoser 2008) and health and wellbeing (Nimegeer et al. 2018, Anciaes et al. 2019).

Increased awareness of these consequences has led governments to reduce severance using a range of policies (Future of London 2018). This includes redesigning road infrastructure (reducing number of lanes, or adding a central reservation), adding or improving crossing facilities, reducing traffic volumes and speeds and, more radically, removing the infrastructure altogether (Bocarejo et al. 2012).

\section{How is this impact assessed?}

Severance is usually not assessed at all or assessed using qualitative scales (Anciaes et al. 2016). For example, national guidance for transport appraisal in New Zealand describes several variables to describe the anticipated impacts of policies on walking trips (NZTA 2018 Ch. A8.8). In England, this type of information is translated into a 4-point scale (DfT 2017 Ch.5) and in Switzerland, it used to be translated into an overall score based on pedestrian detour (ASTRA 2010 Ch.6U141), although this has been dropped from recent guidance 
(ASTRA 2018). Guidelines in Germany, Italy, and Australia suggest a simple formula to value road-based severance, multiplying time losses for pedestrians by the unit value of time (BMVI 2016, MIT 2008, ATAP 2018). Similar methods have been used in the literature for the case of railway-based severance (Chang et al. 2014, Ecoplan and INFRAS 2014).

\section{How could the impact be assessed?}

Anciaes et al. (2018) used a stated preference study to value the reduction of severance due to changes in road design, traffic volumes and speeds, and crossing facilities. Stated preference methods have also been used to value policies to remove (rather than reduce) severance, using data from contingent valuation (Grudemo et al. 2002) and choice experiments (Grisolía et al. (2015). Revealed preference methods have also been used to estimate the impact on house prices of projects to bury roads (Kang and Cervero 2009) and railways (Lee and Sohn 2014). Other studies estimated associations between house prices and motorised traffic volumes or number of road lanes (Kawamura and Mahajan 2005, Li and Saphores 2012, Eliasson et al. 2002). The cost of severance can also be estimated by accounting its consequences. For example, Saelensminde (2004) forecast the effects of severance on the number of suppressed walking trips and then monetised the resulting health and safety impacts and the costs of the associated increases in motorised trips.

\section{What are the main issues?}

Severance might be regarded by some of the affected people as a benefit, not as a cost. For example, transport infrastructure may define borders separating communities that do not wish to be connected. It is also difficult to estimate the impact of barriers on walking trip suppression, as this depends on trip purpose, location of trip attractors, and psychological and social aspects. As in the case of visual blight, it is also likely that the perception of severance changes over time, as people and land uses adapt to the presence of infrastructure and traffic. There is also little evidence on the cost of "absolute" barriers, such as motorways and railways, which can only be crossed in a limited number of (grade-separated) crossing facilities, and where safety issues are less relevant than mobility and psychological aspects.

\subsection{Equity and social inclusion}

\section{What is this impact?}

Traditionally, transport policy was mostly concerned with efficiency issues, but there is now an increased interest on equity (Di Ciommo and Shiftan 2017). Equity issues arise because the 
positive and negative impacts of transport policies are not equally distributed among different groups. For example, there is evidence that low-income households and/or ethnic minorities tend to be disproportionately exposed to transport noise and air pollution (Carrier et al. 2016, Li et al. 2018). At the same time, groups such as women, young adults, the elderly, people with disabilities, single parents, carers, low-income households, and ethnic minorities often face restrictions to travel, due to physical, geographic, time, economic, social, or cultural factors (Uteng and Cresswell 2008, Rajé 2017). Those restrictions reduce the ability of these groups to access employment, education, healthcare, and recreation, increasing their risk of social exclusion (Hine and Mitchell 2003). This is then related to poor health and wellbeing (Mackett and Thoreau 2015).

Equity and social inclusion has been addressed through the provision of good-quality and affordable public transport (SEU 2003) and of safe and inclusive walking and cycling infrastructure and public spaces, including adequate provision for people with restricted mobility (NACTO 2016).

\section{How is this impact assessed?}

Equity is sometimes implicitly assessed by using 'equity values' (i.e. the same values for all individuals affected by an impact) or weighting impacts by relative income (to mitigate the fact that willingness to pay depends on ability to pay). More often, equity is addressed simply by disaggregating impacts according to social groups. This information is then analysed in different ways. For example, the national guidance in England suggests a 7-point scale to assess the distribution of each impact (DfT 2015) and the one in France recommends a combination of overall indicators of equity and detailed mapping analysis (CGSP 2013). However, in urban mobility plans, equity is not always translated into specific indicators and tends to be given less priority than environmental issues (Manaugh et al. 2015).

Social inclusion is only partly addressed. Impacts on accessibility and affordability of transport services are included in guidelines in several countries and assessed with qualitative scales (DfT 2017, Ch7-8, ATAP 2018). At the city-level, only a few cities conduct detailed quantitative analyses of equity in accessibility or look at destinations other than jobs (Boisjoly and El-Geneidy 2017). Aspects such as social and cultural barriers tend to be addressed in broad descriptive terms. There are also few methods to quantify gender equality in transport (but see the SKL (2013) guidelines for Swedish local authorities). 


\section{How could the impact be assessed?}

Weights could go beyond a simple correction of different abilities to pay, and express an explicit social priority towards the welfare of some groups. For example, weights could be assigned according to need or vulnerability. But this sort of "ethical weights" is likely to be controversial.

Social inclusion could be valued by monetising its wider consequences on poverty, unemployment, tax contributions, and social security payments. As an alternative, Stanley et al. (2012) suggests a model that estimates the trade-off between income and number of trips in reducing social exclusion. But ideally, accounting for equity should involve shifting the "object of distribution" from the number of trips or travel time to accessibility. For example, Nahmias-Biran and Shiftan (2016) suggest a framework based on the "subjective value of accessibility" and Martens and Di Ciommo (2017) suggest using "equity values of accessibility gains". There is also a vast literature mapping and analysing levels of accessibility of different groups (see Grengs 2015 and El-Geneidy et al. 2016 among others) and a few example of studies using logsum measures to monetize that accessibility (Bills and Walker 2017). However, this research has only slowly been integrated into policy (Papa et al. 2016).

\section{What are the main issues?}

Equity is a political and ethical issue that is difficult to quantify. The first question is to define the relevant social groups in the assessment of each impact. There are also competing views regarding the desirable equity goal: equalize benefits and costs, equalize across groups, provide minimum standards to all, or give higher priority to vulnerable groups. There is also uncertainty regarding which groups will have the benefits and costs of transport policies. In particular, due to market pressures, current residents may be replaced by wealthier residents in areas where transport and place quality has improved.

\subsection{Health and wellbeing}

\section{What is this impact?}

There are several pathways linking transport with health and wellbeing. Transport enhances independent mobility, which is a key component of wellbeing (Delbosc 2012). Walking and cycling are also physical activities and facilitate social interaction, both aspects being positively associated with physical and mental health and subjective wellbeing (Avila- 
Palencia et al. 2018). In contrast, motorised transport is a major source of traffic-related injuries and has negative environmental impacts, such as noise and air pollution, which are linked to several health issues (Nicolopoulou-Stamati et al. 2006). Transport also has several impact on stress, both for travellers (associated with long commutes and congested or overcrowded conditions) (Rüger et al. 2017) and non-travellers (associated with noise annoyance and other nuisances associated living close to busy roads) (Yang and Matthews 2010).

All these impacts on health and wellbeing then have consequences on short or long-term absence from work, productivity, health care costs, and mortality risk. As mentioned in the previous section, poor health and wellbeing is also related to social exclusion (Mackett and Thoreau 2015).

The relationships between transport, health, and wellbeing have become a key focus of transport policy and have been often used as the main rationale for most types of interventions that give priority to non-motorised modes and to the place function of streets in detriment of car traffic (see for example TfL 2014, 2017a).

\section{How is this impact assessed?}

The valuation of health impacts of transport policies often uses the Health Economic Assessment Tool (WHO 2017), which calculates the reduced mortality risk that results from more regular physical activity and reduced road crashes and air pollution. The result is then multiplied by the unit monetary value of a prevented fatality, which is based on estimates of people's willingness to pay for policies that reduce their annual risk of dying (OECD 2012). The valuation of morbidity usually accounts the costs of work absenteeism, an approach included, for example, in the national guidance in England and Ireland (DfT 2018, TII 2016a). Transport for London also uses a 'Sickness Absence Reduction Tool' (TfL 2015). Alternatives include valuing the financial cost of illness for the individual or for the public health system or people's willingness to pay for quality- or disability-adjusted life years (see for example the Australian guidance (ATAP 2016 Ch.5.3)). All these methods apply mainly to physical health impacts. The impacts on mental health and subjective wellbeing are usually not valued.

The value of health impacts associated with exposure to noise and air pollution are usually treated as indicators of the cost of those two impacts and integrated into the calculation of the environmental cost of transport policies. 


\section{How could the impact be assessed?}

There is a fast-growing literature on the valuation of the health benefits of active travel (see a review in Brown et al. 2016) but less evidence on the impacts of transport on mental health and subjective wellbeing. These could be captured using surveys to people affected by different levels of those impacts. This approach has been used to study the impacts of living close to busy roads (Yamazaki et al. 2005, Gundersen et al. 2013) and being exposed to roadside noise (Dratva et al. 2010, Oiamo et al. 2015). An alternative could be to link health impacts with medical costs or with individual outcomes (e.g. employment status) or social outcomes (e.g. community participation or social cohesion), which could then be valued.

\section{What are the main issues?}

Valuation methods tend to rely on many assumptions. This is because it is difficult to build a robust dose-response function that isolates the links between transport and health/wellbeing and to forecast the impacts of specific interventions. For example, the benefits of physical activity only apply to regular walking or cycling behaviour by people who are currently not fully active and can be due to an increase in the number of trips or to an increase in the duration or frequency of existing trips. The benefits also depend on age and local conditions such as air pollution. There are also issues in the integration of health impacts on cost-benefit analysis of policies that promote walking, as in theory, increases in walking time can be accounted simultaneously as a health benefit and as a travel time cost.

\section{Conclusions}

Transport policy is moving from a car-centred to a people-centred paradigm, with growing emphasis on improving aspect of liveability. To be effective, this move requires a parallel change in transport appraisal methods. This paper reviewed the state-of-the-art in methods to assess nine impacts that are relevant to a transport policy focused on liveability, looking specifically at aspects of movement and "place" and at impacts on society. As shown in Table 2, five of the impacts examined are already measured and sometimes monetised by practitioners, although in many cases the methods have been integrated in national guidance, or used by private companies, and may be difficult to apply by city governments. Another two impacts (community severance and equity/social inclusion) could be monetised, using existing methods available in the literature. It is still difficult to monetise time use in transport and visual blight without further methodological developments. However, in recent years 
there were relevant advances in stated and revealed preference models. New types of data could also improve the measurement of the current situation regarding some impacts (e.g. trip quality, time use in places, visual blight), although it is less clear how they could be used to forecast future impacts or be integrated in appraisal.

It should be noted that the table is the authors' general assessment of the existing literature and there are nuances in how different aspects of the nine impacts shown in the table are or could be monetised. For example, the scope for monetising equity depends on the relevant social groups and equity goals considered in each particular project. In addition, some methods may apply to the assessment of social inclusion but not of other equity aspects.

Table 2: Appraisal of liveability impacts of transport: state of the art

\begin{tabular}{llccc}
\hline & & $\begin{array}{c}\text { Already } \\
\text { monetised }\end{array}$ & $\begin{array}{c}\text { Could be } \\
\text { monetised using } \\
\text { existing methods }\end{array}$ & $\begin{array}{c}\text { Difficult to } \\
\text { monetise with } \\
\text { existing methods }\end{array}$ \\
\hline MOVEMENT & $\begin{array}{l}\text { Trip quality } \\
\text { Time use in transport }\end{array}$ & $\mathrm{X}$ & & $\mathrm{X}$ \\
\hline \multirow{2}{*}{ PLACE } & $\begin{array}{l}\text { Place quality } \\
\text { Time use in places }\end{array}$ & $\mathrm{X}$ & & \\
\hline \multirow{5}{*}{ SOCIETY } & Visual blight & & $\mathrm{X}$ & $\mathrm{X}$ \\
& $\begin{array}{l}\text { Community severance } \\
\text { Personal security } \\
\text { Equity and social inclusion } \\
\text { Health and wellbeing }\end{array}$ & $\mathrm{X}$ & $\mathrm{X}$ & \\
& & $\mathrm{X}$ & $\mathrm{X}$ & \\
\hline
\end{tabular}

The main pitfall in including aspects of liveability in transport appraisal is double counting, because, as mentioned in the review sections, and synthesized in Figure 6, there are several relationships between the nine impacts examined in this paper. In particular, health and wellbeing are related to all other impacts. There are also relationships, not shown in the figure but mentioned in the review sections, between the nine impacts and other aspects of liveability, such as noise, air pollution, and traffic safety. Disentangling the value of the different impacts could be achieved by determining causality and analysing the mediating, moderating, and interaction mechanisms underlying the different relationships. For example, the impact on health and wellbeing could be modelled as a set of pathways, some of them including the other eight impacts. The various relationships between the different impacts could then be made explicit as a part of the appraisal process, to ensure that decision-makers are aware of them.

A simpler solution would be to assume that some impacts overlap, i.e. they measure the same aspect. In that case, one impact could be replaced with the other in the assessment, or included as an attribute of the other. For example, time use in transport and time use in places 
could be considered as aspects of trip quality and place quality, respectively, and personal security and visual blight could be considered aspects of both trip quality and place quality.

\section{Figure 6: Relationships between liveability impacts of transport}

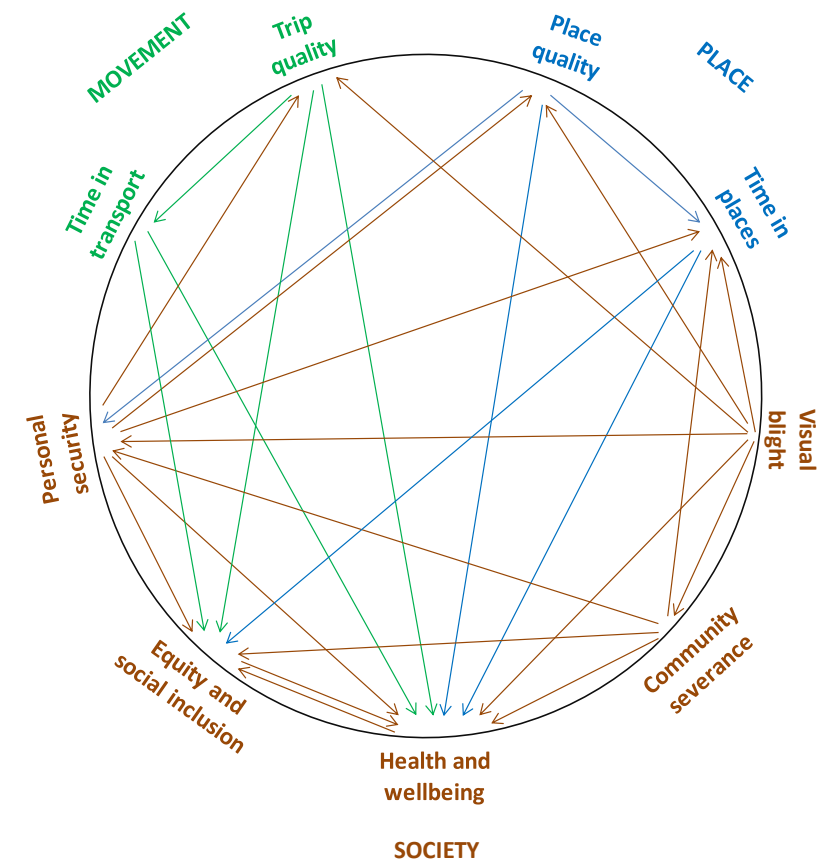

Even without considering possible double counting, the appraisal of each of the nine individual impacts is also complicated by the fact they are multidimensional, difficult to describe with single indicators. As a result, their monetisation implies the forecasting of many variables and using stated or revealed preference methods with many attributes. Impacts are also experienced in different ways by different people in different areas at different times, as they capture subjective aspects of liveability. As mentioned before, impacts such as place quality and community severance are regarded as a benefit for some people and as a cost for others. Benefits in one neighbourhood may also imply costs in another. This raises political questions regarding the prioritization of different preferences for each policy. The increased complexity also restricts the transferability of results across different cities or regions, which depends on the characteristics of the impacts and population affected and on the social and political context.

Governments also need to define the 'correct' spatial and temporal scale over which to aggregate the benefits of transport policies. Policies such as the improvement of trip quality and place quality generate benefits not only for the local residents but also for people who only use the transport system and public spaces sporadically. There is also uncertainty in the forecast of future impacts. Age, socio-economic characteristics, and perceptions change over 
time, especially regarding subjective impacts such as community severance and the visual blight of infrastructure.

More generally, it is likely that policy concerns keep evolving. The increasing pressures on urban space and the emergence of new transport modes and technologies, new production and consumption patterns, and new types of data, may lead governments to seek the joint optimisation of the provision of transport and other goods and services. The relevant impacts for appraisal would then be the benefits and costs of decisions made in the transport sector for other sectors, and vice-versa. This could include, for example, aspects such as overall levels and efficiency of resource use, and the time people spend on different activities (in-home and out-of-home).

\section{Acknowledgements}

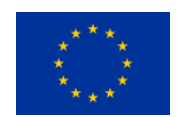

This project has received funding from the European Union's Horizon 2020 research and innovation programme under grant agreement $\mathrm{N}^{\circ} .636573$. This document reflects only the authors' view and neither the Innovation and Networks Executive Agency nor the European Commission is responsible for any use that may be made of the information it contains.

\section{References}

Anciaes, P R., Jones, P. (2016) The effectiveness of changes in street layout and design for reducing barriers to walking. Transportation Research Record 2586, 39-47.

Anciaes, P R., Jones, P., Metcalfe, P J. (2018) A stated preference model to value reductions in community severance caused by roads. Transport Policy 64, 10-19.

Anciaes, P R., Jones, P., Mindell, J M. (2016) Community severance: where is it found and at what cost? Transport Reviews 36(3), 293-317.

Anciaes, P., Stockton, J., Ortegon, A., Scholes, S. (2019) Perceptions of road traffic conditions along with their reported impacts on walking are associated with wellbeing. Travel Behaviour and Society 15, 88101.

Appleyard, B., Ferrell, C E., Carroll, M A., Taecker, M. (2014) Toward livability ethics - a framework to guide planning, design, and engineering decisions. Transportation Research Record 2403, 62-71.

Appleyard, D., Gerson M S., Lintell, M. (1981) Livable Streets. University of California Press, London.

Arenas, J P. (2008) Potential problems with environmental sound barriers when used in mitigating surface transportation noise. Science of the Total Environment 405(1-3), 173-179. 
ASTRA [Bundesamt für Strassen] [Federal Roads Office - Switzerland] (2010) Handbuch NISTRA 2010 [Sustainability indicators for road infrastructure projects - Handbook 2010], https://www.astra.admin.ch/dam/astra/de/dokumente/fachdokumente_fuernationalstrassen/nistrahandbuch-2010.pdf.download.pdf/Handbuch\%20NISTRA\%202010.pdf [in German]

ASTRA [Bundesamt für Strassen] [Federal Roads Office - Switzerland] (2018) Handbuch NISTRA 2018 [Sustainability indicators for road infrastructure projects - Handbook 2018], https://www.astra.admin.ch/dam/astra/de/dokumente/fachdokumente_fuernationalstrassen/handbuch_eni stra.pdf.download.pdf/Handbuch\%20eNISTRA\%20(Version\%202017).pdf [in German]

ATAP (Australian Transport Assessment and Planning Steering Committee) (2016) Australian Transport Assessment and Planning Guidelines Part M4: Active Travel, https://atap.gov.au/mode-specificguidance/active-travel/files/m4_active_travel.pdf

ATAP (Australian Transport Assessment and Planning Steering Committee) (2018) Australian Transport Assessment and Planning Guidelines Part O3: Urban Amenity and Liveability, https://atap.gov.au/otherguidance/urban-amenity-liveability/files/o3-urban-amenity-liveability.pdf

Austroads (2016) Guide to Traffic Management Part 4 Network Management. Austroads, Canberra.

Avila-Palencia, I., Panis L I., Dons, E., Gaupp-Berghausen, M., Raser, E., Götschi, T., Gerike, R., Brand, C., Nazelle, A., Orjuela J P., Anaya-Boig, E., Stigell, E., Kahlmeier, S., Iacorossi, F., Nieuwenhuijsen, M J. (2018) The effects of transport mode use on self-perceived health, mental health, and social contact measures: a cross-sectional and longitudinal study. Environment International 120, 199-206.

Backer-Grøndahl, A., Fyhri, A., Ulleberg, P., Amundsen, A H. (2009) Accidents and unpleasant incidents: worry in transport and prediction of travel behavior. Risk Analysis 29(9), 1217-1226.

Bateman, I., Day, B., Lake, I., Lovett, A. (2001) The Effect of Road Traffic on Residential Property Values: A Literature Review and Hedonic Pricing Study. Scottish Executive and The Stationery Office, Edinburgh, http://www.scotland.gov.uk/Publications/2001/07/9535/File-1

Bayley, M., Curtis, B., Lupton, K., Wright, C. (2004) Vehicle aesthetics and their impact on the pedestrian environment. Transportation Research D 9(6), 437-450.

Becker, J U., Albers, S. (2016) The limits of analyzing service quality data in public transport. Transportation 43(5), 823-842.

Biddulph, M. (2012) Radical streets? The impact of innovative street designs on liveability and activity in residential areas. Urban Design International 17(3), 178-205.

Bills, T S., Walker, J L. (2017) Looking beyond the mean for equity analysis: examining distributional impacts of transportation improvements. Transport Policy 54, 61-69.

BMVI (Federal Ministry of Transport and Digital Infrastructure - Germany) (2016) Methodology Manual for the Federal Transport Infrastructure Plan 2030, http://www.bmvi.de/SharedDocs/EN/Documents/G/methodology-manual-for-the-ftip2030.pdf? blob=publicationFile 
Bocarejo, J P., Le Compte, M C., Zhou, J. (2012) The Life and Death of Urban Highways. Institute for Transportation and Development Policy and EMBARQ, New York and Washington, https://www.itdp.org/2012/03/13/the-life-and-death-of-urban-highways

Boisjoly, G., El-Geneidy, A M. (2017) How to get there? A critical assessment of accessibility objectives and indicators in metropolitan transportation plans. Transport Policy 55, 38-50.

Börjesson, M. (2012) Valuing perceived insecurity associated with use of and access to public transport. Transport Policy 22, 1-10.

Börjesson, M., Eliasson, J. (2012) The value of time and external benefits in bicycle. Transportation Research Part A: Policy and Practice 46(4), 673-683.

Bosselmann, P., Macdonald, E., Kronemeyer, T. (1999) Livable streets revisited. Journal of the American Planning Association 65(2), 168-180.

Bowers, K J., Johnson, S D., Hirschfield, A F. (2004) Closing off opportunities for crime: an evaluation of alley-gating. European Journal on Criminal Policy and Research 10, 285-308.

Brown, V., Diomedi, B Z., Moodie, M., Veerman, J L., Carter, R. (2016) A systematic review of economic analyses of active transport interventions that include physical activity benefits. Transport Policy $\mathbf{4 5}$, 190-208.

Buehler, R., Pucher, J., Gerike, R., Götschi, T. (2017) Reducing car dependence in the heart of Europe: lessons from Germany, Austria, and Switzerland. Transport Reviews 37(1), 4-28.

Buonanno, P., Montolio, D., Raya-Vílchez, J M (2013) Housing prices and crime perception. Empirical Economics 45(1), 305-321.

CABE (Commission for Architecture and the Built Environment) (2001) The Value of Urban Design, https://www.designcouncil.org.uk/sites/default/files/asset/document/the-value-of-urban-design 0.pdf

CABE Space (Commission for Architecture and the Built Environment - Space) (2007) Paved With Gold: The Real Value Good Street Design, http://webarchive.nationalarchives.gov.uk/20110118095356/http:/www.cabe.org.uk/publications/pavedwith-gold

Cain, K. L., Millstein, R A., Geremia, C M. (2012) Microscale Audit of Pedestrian Streetscapes (MAPS): Data Collection \& Scoring Manual, http://sallis.ucsd.edu/measure_maps.html

Cairns, S., Atkins, S., Goodwin, P. (2002) Disappearing traffic? The story so far. Municipal Engineer 151(1), 13-22.

Canter, D. (1977) The Psychology of Place. The Architectural Press, London.

Carmona, M., Gabrieli, T., Hickman, R., Laopoulou, T., Livingstone, N. (2018) Street appeal: the value of street improvements. Progress in Planning 126, 1-51.

Carmona, M., Tiesdell, S., Heath, T., Oc, T., (2010) Public Places-Urban Spaces. The Dimensions of Urban Design (2nd Edition). Architectural Press, Oxford.

Carrier, M., Apparicio, P., Séguin, A-M. (2016) Road traffic noise in Montreal and environmental equity: what is the situation for the most vulnerable population groups? Journal of Transport Geography 51, 18 . 
Cattell, V., Dines, N., Gesler, W., Curtis, S. (2008) Mingling, observing, and lingering: everyday public spaces and their implications for well-being and social relations. Health and Place 14(3), 544-561.

Cavoli, C. (2018) Past, Present and Future Mobility Challenges and Opportunities - Adana, Amman, Bucharest, Skopje, Tallinn. CREATE Project Deliverable 4.4, http://www.createmobility.eu/create/Publications/Project-deliverables

Ceccato, V., Bamzar, R. (2016) Elderly victimization and fear of crime in public spaces. International Criminal Justice Review 26(2), 115-133.

Ceccato, V., Uittenbogaard, A., Bamzar, R. (2013) Security in Stockholm's underground stations: the importance of environmental attributes and context. Security Journal 26(1), 33-59.

CE Delft, INFRAS, Fraunhofer ISI (2011) External Costs of Transport in Europe. Update Study for 2008. Report for the International Union of Railways UIC, http://www.cedelft.eu/en/publications/download/1301

Centre for London (2017) Ideas Above Your Station: Exploring the Potential for Development at London's Stations, https://www.centreforlondon.org/publication/over-station-development

CGSP (Commissariat Général à la Stratégie et à la Prospective) (2013) Évaluation Socioéconomique des Investissements Publics,

http://www.ladocumentationfrancaise.fr/rapportspublics/134000626/index.shtml [in French]

Chang, J. S., Han, S., Jung, D., Kim, D. (2014) Benefits of rerouting railways to tunnels in urban areas: a case study of the Yongsan line in Seoul. International Journal of Urban Sciences 18(3), 404-415.

Cheliotis, K. (2016) Capturing real-time public space activity using publicly available digital traces. Presented at 12th International AAAI Conference on Web and Social Media, http://www.aaai.org/ocs/index.php/ICWSM/ ICWSM16/paper/download/13210/12852

City of Barcelona (2012) Let's Fill Streets With Life - Establishing Superblocks in Barcelona, http://ajuntament.barcelona.cat/ecologiaurbana/sites/default/files/en_gb_MESURA\%20GOVERN\%20S UPERILLES.pdf

City of Copenhagen (2009) A Metropolis for People - Visions and Goals for Urban Life in Copenhagen 2015, http://kk.sites.itera.dk/apps/kk_pub2/pdf/646_mIr0dQ6Wdu.pdf

City of Copenhagen (2013) Urban Life Account, http://kk.sites.itera.dk/apps/kk_pub2/pdf/ 1258_0B5eEF1cF5.pdf

City of Copenhagen (2015) Municipal Plan 2015 - The Coherent City, https://kp15.kk.dk/sites/kp15.kk.dk/files/municipal_plan_2015.pdf

City of Vienna (2014) Urban Mobility Plan - Vienna, https://www.wien.gv.at/stadtentwicklung/studien/pdf/b008443.pdf

Civic Data Design Lab and Gehl Institute (2017) Benchmark. Gehl Institute, https://gehlinstitute.org/wpcontent/uploads/2018/01/BenchMark_Final.pdf

Colomb, C. (2012) Staging the New Berlin: Place Marketing and the Politics of Urban Reinvention Post1989. Routledge, London and New York. 
COWI (2009) Samfundsøkonomiske Analyser af Cykeltiltag - Metode og Cases [Socio-economic analysis of cycle projects - method and cases]. Economic evaluation of cycle projects: methodology and unit prices. City of Copenhagen, Copenhagen. English summary: http://www.cycling-embassy.dk/wpcontent/uploads/2010/06/COWI_Economic-evaluation-of-cycle-projects.pdf

CRIDF (Conseil Régional d'Île-de-France) (2014) Plan de Déplacements Urbains d'Île-de-France [Urban Travel Plan of Ile-de-France], http://www.pduif.fr/-Le-PDUIF-.html [in French]

Currie, G., Stanley, J. (2008) Investigating links between social capital and public transport. Transport Reviews 28(4), 529-547.

Day, K., Boarnet, M. and Alfonzo, M. (2005) Irvine Minnesota Inventory for Observation of Physical Environment Features Linked to Physical Activity, https://webfiles.uci.edu/kday/public/index.html

De Gruyter, C., Currie, G., Truong, L., Naznin, F. (2019) A meta-analysis and synthesis of public transport customer amenity valuation research. Transport Reviews 39(2), 261-283.

DEFRA (UK Department for Environment, Food and Rural Affairs) (2013) Local Environmental Quality: Valuing the Neighbourhood in Which We Live, https://www.gov.uk/government/publications/localenvironmental-quality-adding-a-monetary-value-guidance

Delbosc, A. (2012) The role of well-being in transport policy. Transport Policy 23, 25-33.

DfT (UK Department for Transport) (2003) Public Transport Needs of Minority Ethnic and Faith. Stationary Office, London, https://webarchive.nationalarchives.gov.uk/20100513131319/ http://www.dft.gov.uk/pgr/inclusion/mef/publictransportneedsofminori3259

DfT (UK Department for Transport) (2015) Distributional Impact Appraisal, TAG Unit A4.2, https://www.gov.uk/government/publications/webtag-tag-unit-a4-2-distributional-impact-appraisaldecember-2015

DfT (UK Department for Transport) (2017) Social Impact Appraisal, TAG Unit A4.1, https://www.gov.uk/government/publications/webtag-tag-unit-a4-1-social-impact-appraisal-december$\underline{2017}$

DfT (UK Department for Transport) (2018) Active Mode Appraisal, TAG Unit A5.1, https://www.gov.uk/government/uploads/system/uploads/attachment_data/file/712970/tag-unit-a5-1active-mode-appraisal-may-2018.pdf

Di Ciommo, F., Shiftan, Y. (2017) Equity in transport (Special issue). Transport Reviews 37(2).

Donovan, G H., Butry, D T. (2010) Trees in the city: valuing street trees in Portland, Oregon. Landscape and Urban Planning 94(2), 77-83.

Dratva, J., Zemp, E., Dietrich, D F., Bridevaux, P-O., Rochat, T., Schindler, C., Gerbase, M W. (2010) Impact of road traffic noise annoyance on health-related quality of life: results from a population-based study. Quality of Life Research 19(1), 37-46. 
Ecoplan and INFRAS (2014) Externe Effekte des Verkehrs 2010: Monetarisierung Von Umwelt-, Unfallund Gesundheitseffekten [External effects of transport 2010: Monetization of environmental, accident and health effects]. Report to the Swiss Federal Office for Spatial Development, https://www.are.admin.ch/are/en/home/media-and-publications/publications/transport/externe-effektedes-verkehrs-2010.html [in German]

El-Geneidy, A., Levinson, D., Diab, E., Boisjoly, G., Verbich, D., Loong, C. (2016) The cost of equity: assessing transit accessibility and social disparity using total travel cost. Transportation Research Part A: Policy and Practice 91, 302-316.

Eliasson, J., Dillén, J L., Widell J. (2002) Measuring intrusion valuations through stated preferences and hedonic prices - a comparative study. AET Papers Repository, https://aetransport.org/public/downloads/jdQO4/510-514ec4e74b792.pdf

Ettema, D., Friman, M., Gärling, T., Olsson, L E., Fujii, S. (2012) How in-vehicle activities affect work commuters satisfaction with public transport. Journal of Transport Geography 24, 215-222.

Ettema, D., Verschuren, L. (2007) Multitasking and value of travel time savings. Transportation Research Record 2010, 19-25.

European Commission (2004) Reclaiming City Streets for People: Chaos or Quality of Life?, http://ec.europa.eu/environment/pubs/pdf/streets_people.pdf

Ewing, R., Clemente, O. (2013) Measuring Urban Design: Metrics for Livable Places. Island Press, Washington.

Ewing, R., Clemente, O., Handy, S., Brownson, R C., Winston, E. (2005) Identifying and Measuring Urban Design Qualities Related to Walkability. Report for the Active Living Research Program, https://activelivingresearch.org/sites/default/files/FinalReport 071605.pdf

Farrington, D P., Gill, M., Waples, S J., Argomaniz, J. (2007) The effects of closed-circuit television on crime: meta-analysis of an English national quasi-experimental multi-site evaluation. Journal of Experimental Criminology 3(1), 21-38.

Frei, C., Mahmassani, H S., Frei, A. (2015) Making time count: traveler activity engagement on urban transit. Transportation Research Part A: Policy and Practice 76, 58-70.

Friman, M., Gärling, T., Ettema, D., Olsson, L E. (2017) How does travel affect emotional well-being and life satisfaction? Transportation Research Part A: Policy and Practice 106, 170-180.

Future of London (2018) Overcoming London's Barriers, https://www.futureoflondon.org.uk/wpcontent/uploads/delightful-downloads/2019/01/Overcoming-Barriers-report-FINAL-low-res.pdf

Gehl, J. (1971) Life Between Buildings. Danish Architectural Press, Skive.

Gehl, J. (2010) Cities for People. Island Press, Washington.

Gehl Institute (n.d.) Using Public Life Tools, https://gehlinstitute.org/tools

Gehl Institute and J. Max Bond Center (2015) Public Life \& Urban Justice in NYC's Plazas. Gehl Institute, https://gehlinstitute.org/wp-content/uploads/2017/02/PublicLifeUrbanJustice_Gehl_2016-1.pdf 
Geurs, K T., Boon, W., Van Wee, B. (2009) Social impacts of transport: literature review and the state of the practice of transport appraisal in the Netherlands and the United Kingdom. Transport Reviews 29(1), 6990.

Giergiczny, M., Kronenberg, J. (2014) From valuation to governance: using choice experiment to value street trees. AMBIO 43, 492-501.

Gill, M., Spriggs, A. (2005) Assessing the Impact of CCTV. Home Office Research Study 292, https://techfak.uni-bielefeld.de/ iluetkeb/2006/surveillance/paper/social_effect/CCTV_report.pdf

Gospodini, A. (2002) European cities in competition and the new 'uses' of urban design. Journal of Urban Design 7(1), 59-73.

Green, J., Jones, A., Roberts, H. (2014) More than A to B: the role of free bus travel for the mobility and wellbeing of older citizens in London. Ageing and Society 34, 472-494.

Grengs, J. (2015) Nonwork accessibility as a social equity indicator. International Journal of Sustainable Transportation 9, 1-14.

Grisolía, J. M., López, F., Ortúzar, J. (2015) Burying the highway: the social valuation of community severance and amenity. International Journal of Sustainable Transportation 9(4), 298-309

Grudemo, S., Ivehammar, P., Sandsröm, J. (2002) Beräkningsmodell för Infrastrukturinvesteringars Intrångskostnader [Calculation model for the encroachment costs of infrastructure investments]. VTI meddelande 939 - 2002. Vag Och Transportforskningsinstitut, Linköping, Sweden., http://www.divaportal.org/smash/get/diva2:673731/FULLTEXT01.pdf [in Swedish]

Guirao, B., García-Pastor, A., López-Lambas, M E. (2016) The importance of service quality attributes in public transportation: narrowing the gap between scientific research and practitioners' needs. Transport Policy 49, 68-77.

Gundersen, H., Magerøy, N., Moe, B E., Bråtveit, M. (2013) Traffic density in area of residence is associated with health-related quality of life in women - the community-based Hordaland Health Study. Archives of Environmental and Occupational Health 68(3), 153-160.

Guo, Z., Derian, A., Zhao, J. (2015) Smart devices and travel time use by bus passengers in Vancouver, Canada. International Journal of Sustainable Transportation 9(5), 335-347.

Guo, Z., Loo, B P Y. (2013) Pedestrian environment and route choice - evidence from NYC and Hong Kong. Journal of Transport Geography 28, 124-136.

Halpern, C., Persico, S., Orlandi, C., Vergara, M. (2018) Transport Policy Developments: Western European Cross-city comparisons. CREATE Project http://nws.eurocities.eu/MediaShell/GetMediaBytes?mediaReference=id173988

Hamersma, M., Tillema, T., Sussman, J., Arts, J. (2014) Residential satisfaction close to highways: the impact of accessibility, nuisances and highway adjustment projects. Transportation Research Part A: Policy and Practice 59, 106-121.

Highways Agency [England] (2010) Landscape and Visual Effects Assessment. Interim Advice Note 135/10, http://www.standardsforhighways.co.uk/ha/standards/ians/pdfs/ian135.pdf

Hine, J., Mitchell, F., (2003) Transport Disadvantage and Social Exclusion: Exclusionary Mechanisms in transport in Urban Scotland. Aldershot, Ashgate. 
ITF (International Transport Forum) (2014) Valuing Convenience in Public Transport. Roundtable Report 156, http://www.oecd.org/publications/valuing-convenience-in-public-transport-9789282107683-en.htm

ITS (University of Leeds Institute for Transport Studies) and Atkins (2011) Valuation of Townscapes and Pedestrianisation. Report for the UK Department for Transport, https://www.gov.uk/government/publications/valuation-of-townscapes-and-pedestrianisation

Jacobs, J. (1961) The Death and Life of Great American Cities. Random House, New York.

Jacobsen, P L., Racioppi, F., Rutter, H. (2009) Who owns the roads? How motorised traffic discourages walking and bicycling. Injury Prevention 15(6), 369-373.

Jain, J. Lyons, G. (2008) The gift of travel time. Journal of Transport Geography 16(2), 81-89.

James, E., Millington, A., Tomlinson, P. (2005) Understanding Community Severance, Part 1: Views of Practitioners and Communities. Report for UK Department for Transport, http://webarchive.nationalarchives.gov.uk/+/http://www.dft.gov.uk/adobepdf/163944/Understanding_Co mmunity_Sev1.pdf

Jánošíková, L., Slavík, J., Koháni, M. (2014) Estimation of a route choice model for urban public transport using smart card data. Transportation Planning and Technology 37(7), 638-648.

Jerrett, M., McConnell, R., Chang, C C R., Wolch, J., Reynolds, K., Lurmann, F., Gilliland, F., Berhane, K. (2010) Automobile traffic around the home and attained body mass index: a longitudinal cohort study of children aged 10-18 years. Preventive Medicine 50(S1), 50-58.

Jiang, L., Kang, J. (2016) Combined acoustical and visual performance of noise barriers in mitigating the environmental impact of motorways. Science of the Total Environment 543, 52-60.

Jiang, L., Kang, J., Schroth, O. (2015) Prediction of the visual impact of motorways using GIS. Environmental Impact Assessment Review 55, 59-73.

Jones, P. (2014) The evolution of urban mobility: the interplay of academic and policy perspectives. IATSS Research 38(1), 7-13.

Jones, P. M., Boujenko, N., Marshall, S. (2007) Link and Place: A Guide to Street Planning and Design. Landor Publishing, London.

Jones, P., Anciaes, P., Buckingham, C., Cavoli, C., Cohen, T., Cristea, L., Gerike, R., Halpern, C., Pickup, L. (2018) Urban Mobility: Preparing for the Future, Learning from the Past, http://nws.eurocities.eu/MediaShell/GetMediaBytes?mediaReference=id173997

Kang, C D., Cervero, R. (2009) From elevated freeway to urban greenway: land value impacts of CGC project in Seoul, Korea. Urban Studies 46(13), 2771-2794.

Kaplan, R. (2001) The nature of the view from home: psychological benefits. Environment and Behavior 33(4), 507-542.

Kawamura, K., Mahajan, S. (2005) Hedonic analysis of impacts of traffic volumes on property values. Transportation Research Record 1924, 69-75.

Kelly, C E., Tight, M R., Hodgson, F C., Page, M W. (2011) A comparison of three methods for assessing the walkability of the pedestrian environment. Journal of Transport Geography 19, 1500-1508. 
Keseru, I., Macharis, C. (2018) Travel-based multitasking: review of the empirical evidence. Transport Reviews 38(2), 162-183.

Kim, H. (2015) Walking distance, route choice, and activities while walking: a record of following pedestrians from transit stations in the San Francisco Bay area. Urban Design International 20(2), 144157.

Kouwenhoven, M., De Jong, G. (2018) Value of travel time as a function of comfort. Journal of Choice Modelling 28, 97-107.

Korzhenevych, A., Dehnen, N., Bröcker, J., Holtkamp, M., Meier, H., Gibson, G., Varma, A., Cox, V. (2014) Update of the Handbook on External Costs of Transport. Report for the European Commission (DG MOVE), https://ec.europa.eu/transport/sites/transport/files/themes/sustainable/studies/doc/2014handbook-external-costs-transport.pdf

Lawson, T., Rogerson, R., Barnacle, M. (2018) A comparison between the cost effectiveness of CCTV and improved street lighting as a means of crime reduction. Computers, Environment and Urban Systems $\mathbf{6 8}$, $17-25$.

Lee, J., Sohn, K. (2014) Identifying the impact on land prices of replacing at-grade or elevated railways with underground subways in the Seoul metropolitan area. Urban Studies 51(1), 44-62.

Li, V O K., Han, Y., Lam, J C K., Zhu, Y., Bacon-Shone, J. (2018) Air pollution and environmental injustice: are the socially deprived exposed to more $\mathrm{PM}_{2.5}$ pollution in Hong Kong? Environmental Science and Policy 80, 53-61.

Li, W., Saphores, J-D. (2012) Assessing impacts of freeway truck traffic on residential property values southern California case study. Transportation Research Record 2288, 48-56.

Liotopoulos, F K. (2017) Enhanced transport survey tools in location-aware devices., in M Tovey, A Woodcock, and J Osmond (Eds.) Designing Mobility and Transport Services - Developing Traveller Experience Tools. Routledge, London., 113-126.

Lorenc, T., Petticrew, M., Whitehead, M., Neary, D., Clayton, S., Wright, K., Thompson, H., Cummins, S., Sowden, A., Renton, A. (2013) Environmental interventions to reduce fear of crime: systematic review of effectiveness. Systematic Reviews 2:30.

Loukaitou-Sideris, A. (2014a) Safe on the move: the importance of the built environment., in V Ceccato (Ed.) The Urban Fabric of Crime and Fear. Springer, Dordrecht., 86-110.

Loukaitou-Sideris, A. (2014b) Fear and safety in transit environments from the women's perspective. Security Journal 27(2), 242-256.

Lyons, G., Jain, J., Holley, D. (2007) The use of travel time by rail passengers in Great Britain. Transportation Research Part A: Policy and Practice 41 (1), 107-120.

Mackett, R L., Thoreau, R. (2015) Transport, social exclusion and health. Journal of Transport and Health 2(4), 610-617. 
Mackie, P., Worsley, T. (2013) International Comparisons of Transport Appraisal Practice - Overview Report. Report to UK Department for Transport. Institute for Transport Studies, University of Leeds, https://www.gov.uk/government/uploads/system/uploads/attachment_data/file/209530/final-overviewreport.pdf

Mahmoudi, M., Ahmad, F. (2015) Determinants of livable streets in Malaysia: a study of physical attributes of two streets in Kuala Lumpur. Urban Design International 20(2), 158-174.

Malokin, A., Circella, G., Mokhtarian, P L. (2019) How do activities conducted while commuting influence mode choice? Using revealed preference models to inform public transportation advantage and autonomous vehicle scenarios. Transportation Research Part A: Policy and Practice 124, 82-114.

Manaugh, K., Badami, M G., El-Geneidy, A M. (2015) Integrating social equity into urban transportation planning: a critical evaluation of equity objectives and measures in transportation plans in North America. Transport Policy 37, 167-176.

Martens, K., Di Ciommo, F. (2017) Travel time savings, accessibility gains and equity effects in costbenefit analysis. Transport Reviews 37(2), 152-169.

Mayor of London (2018) Mayor's Transport Strategy, https://www.london.gov.uk/what-wedo/transport/our-vision-transport/mayors-transport-strategy-2018

Mindell, J S., Karlsen, S. (2012) Community severance and health: what do we actually know? Journal of Urban Health 89(2), 232-246.

Mindell, J S., Anciaes, P R., Dhanani, A., Stockton, J., Jones, P., Haklay, M., Groce, M., Scholes, S., Vaughan, L. (2017) Using triangulation to assess a suite of tools to measure community severance. Journal of Transport Geography 60, 119-129.

MIT (Ministero delle Infrastrutture e dei Trasporti) [Ministry of Infrastructure and Transport - Italy]. (2008) Linee Guida Per La Misura Dei Costi Esterni Nell'ambito Del PON Trasporti 2000-2006 [Guidelines for the measurement of external costs as part of the 2000-2006 national operational programme for transport]. Quaderni del PON Trasporti 8, http://www.scuolavas.it/index.php/lgintroduzione/componenti-e-fattori-ambientali/mobilita-e-trasporti/viewdownload/10-mobilita-etrasporti/91-linee-guida-per-la-misura-dei-costi-esterni-nell-ambito-del-pon-trasporti-2000-2006-2008 [In Italian]

Mokhtarian, P L., Salomon, I. (2001) How derived is the demand for travel? Some conceptual and measurement considerations. Transportation Research Part A: Policy and Practice 35 (8), 695.719.

Mullan, E. (2003) Do you think that your local area is a good place for young people to grow up? The effects of traffic and car parking on young people's views. Health and Place 9(4), 351-360.

Muraleetharan, T., Hagiwara, T. (2007) Overall level of service of urban walking environment and its influence on pedestrian route choice behavior: analysis of pedestrian travel in Sapporo, Japan. Transportation Research Record 2002, 7-17.

Musterd, S., Kovács, Z. (Eds.) (2013) Place-making and Policies for Competitive Cities. Wiley-Blackwell, Chichester. 
NACTO (National Association of City Transportation Officials) (2016) Global Street Design Guide. NACTO, New York, https://globaldesigningcities.org/publication/global-street-design-guide

Nahmias-Biran, B., Shiftan, Y. (2016) Towards a more equitable distribution of resources: using activitybased models and subjective well-being measures in transport project evaluation. Transportation Research Part A: Policy and Practice 94, 672-684.

Newman, P., Kenworthy, J. (2015) The End of Automobile Dependence: How Cities are Moving Beyond Car-based Planning. Island Press, Washington.

Nicolopoulou-Stamati, P., Hens, L., Howard, C V. (2006) Environmental Health Impacts of Transport and Mobility. Springer, Dordrecht.

Nieuwenhuijsen, M J., Khreis, H. (2016) Car free cities: pathway to healthy urban living. Environment International 94, 251-262.

Nimegeer, A., Thomson, H., Foley, L., Hilton, S., Crawford, F., Ogilvie, D. (2018) Experiences of connectivity and severance in the wake of a new motorway: Implications for health and well-being. Social Science and Medicine 197, 78-86.

Noland, R B., Weiner, M D., Gao, D., Cook, M P., Nelessen, A. (2017) Eye tracking technology visual preference surveys and urban design preliminary evidence of an effective methodology. Journal of Urbanism 10(1), 98-110.

NYC DoT (New York City Department of Transport) (2012) Measuring the Street: New Metrics for 21st Century Streets, http://www.nyc.gov/html/dot/downloads/pdf/2012-10-measuring-the-street.pdf

NYC DoT (New York City Department of Transport) (2013) The Economic Benefits of Sustainable Streets, http://www.nyc.gov/html/dot/downloads/pdf/dot-economic-benefits-of-sustainable-streets.pdf

NYC DoT (New York City Department of Transport) and Gehl Architects (2008) World Class Streets: Remaking New City's Public Realm, http://www.nyc.gov/html/dot/downloads/pdf/World_Class_Streets_Gehl 08.pdf

NZTA (New Zealand Transport Agency) (2018) Economic Evaluation Manual. NZTA, Wellington, https://www.nzta.govt.nz/resources/economic-evaluation-manual

Odgaard, T., Kelly, C., Laird, J. (2005) Current Practice in Project Appraisal in Europe. HEATCO project Deliverable https://trimis.ec.europa.eu/sites/default/files/project/documents/20130122_113558_74349_hd1final.pdf

OECD (Organisation for Economic Co-operation and Development) (2012) Mortality Risk Valuation in Environment, Health, and Transport Policies. OECD, Paris.

Oiamo, T H., Luginaah, I N., Baxter, J. (2015) Cumulative effects of noise and odour annoyances on environmental and health related quality of life. Social Science and Medicine 146, 191-203.

Oña, J., Oña, R. (2015) Quality of service in public transport based on customer satisfaction surveys: a review and assessment of methodological approaches. Transportation Science 49(3), 605-622.

Oviedo-Trespalacios, O., Scott-Parker, B. (2017) Footbridge usage in high-traffic flow highways: the intersection of safety and security in pedestrian decision-making. Transportation Research Part F: Traffic Psychology and Behaviour 49, 177-287. 
Painter, K A., Farrington, D P. (2001) The financial benefits of improved street lighting, based on crime reduction. Lighting Research and Technology 33(1), 3-12.

Papa, E., Silva, C., Brömmelstroet, M., Hull, A. (2016) Accessibility instruments for planning practice: a review of European experiences. Journal of Transport and Land Use 9(3), 57-75.

Pearce, D., Atkinson, G., Mourato, S. (2006) Cost-Benefit Analysis and the Environment - Recent Developments. OECD, Paris.

Poorfakhraei, A., Rowangould, G M. (2015) Estimating welfare change associated with improvements in urban bicycling facilities. Journal of Transportation Engineering 141(11):04015025

Rajé, F. (2017) Negotiating the Transport System: User Contexts, Experiences and Needs. Ashgate, Aldershot.

Rasouli, S., Timmermans, H. (2014) Judgements of travel experiences, activity envelopes, trip features and multi-tasking: a panel effects regression model specification. Transportation Research Part A: Policy and Practice 63, 67-75.

Redman, L., Friman, M., Gärling, T., Hartig, T. (2013) Quality attributes of public transport that attract car users: a research review. Transport Policy 25, 119-127.

Redmond, L S., Mokhtarian, P L. (2001) The positive utility of the commute: modeling ideal commute time and relative desired commute amount. Transportation 28(2), 179-205.

Rhee, K-A., Kim, J-K., Lee, B-J., Kim, S., Lee, Y I. (2013) Analysis of effects of activities while traveling on travelers' sentiment. Transportation Research Record 2383, 27-34.

Rüger, H., Pfaff, S., Weishaar, H., Wiernik, B M. (2017) Does perceived stress mediate the relationship between commuting and health-related quality of life? Transportation Research Part F: Traffic Psychology and Behaviour 50, 100-108.

Saelens, B E., Sallis, J F., Frank, L D. (2003) Environmental correlates of walking and cycling: findings from the transportation, urban design, and planning literatures. Annals of Behavioral Medicine 25(2), 8091.

Sauter, D., Huettenmoser, M. (2008) Livable streets and social inclusion. Urban Design International 13(2), 67-79.

Sælensminde, K. (2004) Cost-benefit analyses of walking and cycling track networks taking into account insecurity, health effects and external costs of motorized traffic. Transportation Research A 38(8), 593606.

SDG (Steer Davies Gleave) (2011) The Value of Station Investment. Report for Network Rail, http://81.47.175.201/livingrail/attachments/article/665/2011_The_Value_of_Station_Investment_Report. pdf

SenStadt (2011) Stadtentwicklungsplan Verkehr Berlin [Urban Development Plan - Transport], http://www.stadtentwicklung.berlin.de/verkehr/politik_planung/step_verkehr/download/Stadtentwicklun gsplan_Verkehr_Berlin_gesamt.pdf [in German]

SEU (Social Exclusion Unit) (2003) Making the Connections: Final Report on Transport and Social Exclusion, http://www.ilo.org/emppolicy/pubs/WCMS_ASIST_8210/lang--en/index.htm 
Sheldon, R., Heywood, C., Buchanan, P., Ubaka, D., Horrell, C. (2007) Valuing urban realm - business cases in public spaces. AET Papers Repository, https://aetransport.org/en-gb/past-etc-papers/search-alletc-conference-papers?abstractId $=2777 \&$ state $=\mathrm{b}$

Sidebottom, A., Tompson, L., Thornton, A., Bullock, K., Tilley, N., Bowers, K., Johnson, S D. (2018) Gating alleys to reduce crime: a meta-analysis and realist synthesis. Justice Quarterly 35(1), 55-86.

SKL (Sveriges Kommuner Och Landsting) [Swedish Association of Local Authorities and Regions] (2013) Kön i Trafken - Jämställdhet i Kommunal Transportplanering [Gender in traffic - equality in municipal transport planning], http://webbutik.skl.se/bilder/artiklar/pdf/7164-937-9.pdf [in Swedish]

Stanley, S., Stanley, J., Hensher, D. (2012) Mobility, social capital and sense of community: what value? Urban Studies 49(16), 3595-3609.

Stucky, T D., Smith S L (2017) Exploring the conditional effects of bus stops on crime. Security Journal 30(1), 290-309.

Susilo, Y O., Abenoza, R. (2017) METPEX trial results: investigating different key determinants of travel satisfaction for different groups of travellers., in M Tovey, A Woodcock, and J Osmond (Eds.) Designing Mobility and Transport Services - Developing Traveller Experience Tools. Routledge, London., 99-112.

TFL (Transport for London) (2014) Improving the Health of Londoners - Transport Action Plan, https://tfl.gov.uk/cdn/static/cms/documents/improving-the-health-of-londoners-transport-action-plan.pdf

TFL (Transport for London) (2015) Valuing the Health Benefits of Transport Schemes - Guidance for London, http://content.tfl.gov.uk/valuing-the-health-benefits-of-transport-schemes.pdf

TFL (Transport for London) (2017a) Healthy Streets for London, http://content.tfl.gov.uk/healthy-streetsfor-london.pdf

TFL (Transport for London) (2017b) Business Case Development Manual. TfL, London.

TfL (Transport for London) (2017c) Streetscape Guidance, http://content.tfl.gov.uk/streetscape-guidance. $\mathrm{pdf}$

TfL (Transport for London) (2018a) Walking Action Plan: Making London the World's Most Walkable City, http://content.tfl.gov.uk/mts-walking-action-plan.pdf

TfL (Transport for London) (2018b) Cycling Action Plan: Making London the World's Best Big City for Cycling, http://content.tfl.gov.uk/cycling-action-plan.pdf

TfNSW (Transport for New South Wales) (2016) Principles and Guidelines for Economic Appraisal of Transport Investment and Initiatives - Transport Economic Appraisal Guidelines, https://www.transport.nsw.gov.au/sites/default/files/media/documents/2017/principles-and-guidelinesfor-economic-appraisal-of-transport-investment.pdf

TII (Transport Infrastructure Ireland) (2016a) Project Appraisal Guidelines for National Roads Unit 13.0 Pedestrian and Cyclist Facilities, http://www.tiipublications.ie/library/PE-PAG-02036-01.pdf

TII (Transport Infrastructure Ireland) (2016b) Project Appraisal Guidelines for National Roads Unit 7.0 Multi Criteria Analysis, http://www.tiipublications.ie/library/PE-PAG-02031-01.pdf 
Tilahun, N Y., Levinson, D M., Krizek, K J. (2007) Trails, lanes, or traffic - valuing bicycle facilities with an adaptive stated preference survey. Transportation Research Part A: Policy and Practice 41(4), 287301.

Titheridge, H., Achutan, K., Mackett, R., Solomon, J. (2009) Assessing the extent of transport social exclusion among the elderly. Journal of Transport and Land Use 2(2), 31-48.

Trafikverket [Swedish Transport Administration] (2018) Analysmetod Och Samhällsekonomiska Kalkylvärden för Transportsektorn [Analysis Methods and Socioeconomic Estimates for the Transport Sector], $\quad$ https://www.trafikverket.se/contentassets/4b1c1005597d47bda386d81dd3444b24/asek6.1/asek_6_1_hela_rapporten_180412.pdf

TRL (Transport Research Laboratory) (2010) PERS Streetaudit - On-street Assessment Handbook.

ULI (Urban Land Institute) (2016) Building Healthy Corridors - Transforming Urban and Suburban Arterials into Thriving Places., https://uli.org/wp-content/uploads/ULI-Documents/Building-HealthyCorridors-ULI.pdf

US DOT (US Department of Transportation) (2015) Guidelines for the Visual Impact Assessment of Highway Projects, https://www.environment.fhwa.dot.gov/env topics/other topics/VIA Guidelines for Highway Projects .pdf VIA Guidelines for Highway Projects.asp

Uteng, T P., Cresswell, T. (2008) Gendered Mobilities. Routledge, London.

Van Hagen, M., Pruyn, A., Galetzka, M., Kramer, J. (2009) Waiting is becoming fun! The influence of advertising and infotainment on the waiting experience. AET Papers Repository, https://aetransport.org/en-gb/past-etc-papers/search-all-etc-conference-papers?abstractId=3114\&state=b

Vegdirektoratet [Norwegian Public Roads Administration] (2018) Konsekvensanalyser - Veiledning [Impact Assessment - Guidance]. Håndbok V712. Vegdirektoratet, Oslo, https://www.vegvesen.no/fag/veg+og+gate/planlegging/Grunnlagsdata/Konsekvensanalyser $\quad$ [in Norwegian]

Walton, E. (2014) Vital places: facilitators of behavioral and social health mechanisms in low-income neighborhoods. Social Science and Medicine 122, 1-12.

Wardman, M., Lyons, G. (2016) The digital revolution and worthwhile use of travel time: implications for appraisal and forecasting. Transportation 43 (3), 507-530.

Welsh, B P., Farrington, D C. (2008) Effects of improved street lighting on crime. Campbell Systematic Reviews 13, https://campbellcollaboration.org/library/effects-of-improved-street-lighting-on-crime.html

Welsh, B P., Farrington, D C. (2009) Public area CCTV and crime prevention: an updated systematic review and meta-analysis. Justice Quarterly 26(4), 716-745.

WHO (World Health Organisation) (2015) Health 2020: Transport and Health, http://www.euro.who.int/_data/assets/pdf_file/0020/324641/Health-2020-Transport-and-healthen.pdf?ua=1 
WHO (World Health Organisation) (2017) Health Economic Assessment Tools (HEAT) for Walking and for Cycling - Economic Assessment of Transport Infrastructure and Policies - Methods and User Guide on Physical Activity, Air Pollution, Injuries and Carbon Impact Assessments, http://www.euro.who.int/en/health-topics/environment-and-health/Transport-andhealth/publications/2017/health-economic-assessment-tool-heat-for-walking-and-for-cycling.-methodsand-user-guide-on-physical-activity,-air-pollution,-injuries-and-carbon-impact-assessments-2017

WHO (World Health Organisation) and European Commission (2017) Towards More Physical Activity in Cites - Transforming Public Spaces to Promote Physical Activity, http://www.euro.who.int/_data/assets/pdf_file/0018/353043/2017_WHO_Report_FINAL_WEB.pdf

Whyte, W H. (1980) The Social Life of Small Urban Spaces. Project for Public Space, New York.

Willis, K G., Powe, N A., Garrod, G D. (2005) Estimating the value of improved street lighting. Urban Studies 12, 2289-2303

Yamazaki, S., Sokejima, S., Nitta, H., Nakayama, T., Fukuhara, S. (2005) Living close to automobile traffic and quality of life in Japan: a population-based survey. International Journal of Environmental Health Research 15(1), 1-9.

Yamada, H., Shinohara, O., Amano, K., Okada, K. (1987) Visual vulnerability of streetscapes to elevated structures. Environment and Behavior 18(6), 733-754.

Yang, T C., Matthews, S A. (2010) The role of social and built environments in predicting self-rated stress: A multilevel analysis in Philadelphia. Heath and Place 16(5), 803-810.

Yin, L., Cheng, Q., Wang, Z., Shao, Z. (2015) Big data for pedestrian volume: exploring the use of Google Street View images for pedestrian counts. Applied Geography 63, 337-345.

Zhang, J., Timmermans, H. (2010) Scobit-based panel analysis of multitasking behavior of public transport users. Transportation Research Record 2157, 46-53. 